\title{
NIESPRAWCZA ODPOWIEDZIALNOŚĆ KARNA O CHARAKTERZE REPRESYJNYM (KARNYM) W ŚWIETLE KONSTYTUCJI RP (ART. 42 UST. 1)
}

Przepis art. 42 ust. 1 Konstytucji Rzeczypospolitej Polskiej stanowi o ponoszeniu odpowiedzialności karnej przez tego, kto dopuścił się czynu zabronionego pod groźbą kary przez ustawę obowiązująca w czasie jego popełnienia. Ustawodawca wskazuje więc, że sprawca może ponieść odpowiedzialność karną, jeżeli jego zachowanie będzie czynem zabronionym. Czynem zaś jest działanie lub zaniechanie działania, do którego sprawca był zobowiązany. Także przepisy Kodeksu karnego skarbowego (k.k.s.) potwierdzają tę zasadę, określając przy każdym przestępstwie, że jest to własny czyn sprawcy, np. art. 54: „Podatnik, który uchylając się od opodatkowania [...]”, art. 66: „Kto wyroby akcyzowe oznacza nieprawidłowo [...]”, art. 78: „Płatnik, który nie pobiera podatku [...]”, podlega karze.

Przyjąć należy, że art. 42 Konstytucji RP formułuje jedną z podstawowych reguł określająca, jakie funkcje ma spełniać ustawa karna oraz jakich zasad ma przestrzegać organ stosujący szeroko pojęte prawo karne. Z reguły wyrażonej w tym przepisie wynika kilka zaleceń: pierwsze - skierowane do ustawodawcy, aby w procesie tworzenia prawa zasady odpowiedzialności karnej oraz poszczególne przestępstwa zostały wyraźnie określone i zapisane w akcie prawnym jakim jest ustawa, oraz drugie - adresowane do ustawodawcy, aby formułował przepisy karne w sposób zrozumiały i jasny dla każdego obywatela. Trzecie zalecenie, skierowane do organów stosujących prawo, oznacza, że nikt nie może być pociągnięty do odpowiedzialności karnej za czyny, które nie były zabronione w momencie ich popełnienia ${ }^{1}$.

W przepisie art. 42 ust. 1 Konstytucji RP mowa więc o odpowiedzialności sprawczej osoby, która dopuściła się czynu zabronionego. Konstytucja indywidualizuje odpowiedzialność osoby i gwarantuje, że będzie ona podlegała odpowiedzialności karnej jedynie za własny czyn.

W związku z tym, że przepisy ustawy karnej (k.k.) spełniają w zakresie odpowiedzialności postanowienia Konstytucji RP, powstaje pytanie, czy w polskim systemie prawnym przewidziana jest wyłącznie taka odpowiedzialność. Polski ustawodawca wprowadza bowiem także inny rodzaj odpowiedzialności (za cudze czyny): w k.k.s w zakresie odpowiedzialności posiłkowej,

${ }^{1}$ M. Dietrich, B. Namysłowska-Gabrysiak, Prawo karne - część ogólna, Warszawa 2003, s. 5-7. 
k.k. i k.k.s. w zakresie zobowiązania do zwrotu korzyści majątkowej oraz w ustawie o odpowiedzialności podmiotów zbiorowych.

Otóż prawo polskie przewiduje szereg przejawów norm represyjnych, które określić można prawem represyjnym. Poza prawem karnym sa to prawo wykroczeń, prawo karne skarbowe, czy wreszcie odpowiedzialność dyscyplinarna. Przyjmuje się, że zasady wyrażone w art. 42 Konstytucji RP odnoszą się wprost do tego prawa, przy czym do odpowiedzialności dyscyplinarnej stosuje się je odpowiednio ${ }^{2}$.

W niniejszym opracowaniu podjęto próbę określenia relacji pomiędzy art. 42 ust. 1 Konstytucji RP a wymienionymi rodzajami odpowiedzialności za cudze czyny, w tym tego, jak wskazany artykuł ustawy zasadniczej odnieść należy do wymienionych rodzajów odpowiedzialności o charakterze represyjnym. Jest to zagadnienie tym bardziej interesujące, że podnosi się, iż odpowiedzialność za cudze czyny powoduje istotne odstępstwo od przyjętych zasad odpowiedzialności karnej i pociąga za sobą poważne konsekwencje natury konstytucyjnej w kontekście zasady nullum crimen sine actione ${ }^{3}$.

\section{ODPOWIEDZIALNOŚĆ POSIŁKOWA PRZEWIDZIANA W KODEKSIE KARNYM SKARBOWYM}

Odpowiednikiem art. 42 ust. 1 Konstytucji RP jest art. 1 k.k.s., zgodnie z którym odpowiedzialności karnej za przestępstwo skarbowe lub odpowiedzialności za wykroczenie skarbowe podlega ten tylko, kto popełnia czyn społecznie szkodliwy, zabroniony pod groźbą kary przez ustawę obowiązująca w czasie jego popełnienia. O ile zatem Konstytucja określa przestępczość czynu jedynie przez warunek formalny (popełnienie czynu zabronionego przez ustawę pod groźbą kary), o tyle k.k.s. w art. 1 § 1 uwzględnia także warunek materialny, tj. społeczną szkodliwość czynu, bez której to cechy czyn nie może w ogóle być kwalifikowany jako czyn zabroniony. Stopień społecznej szkodliwości czynu przesądza o kwalifikacji tego czynu jako przestępstwa lub wykroczenia skarbowego. Wykroczenia skarbowe sa to bowiem czyny zdecydowanie błahszej natury niż przestępstwa skarbowe.

W związku z takim ujęciem odpowiedzialności karnej (w Konstytucji RP i k.k.s.) należy podkreślić, że akty te normują odpowiedzialność sprawczą osoby, która dopuściła się czynu zabronionego, indywidualizując tę odpowiedzialność. Powstaje więc pytanie, czy normowana przepisami k.k.s. odpowiedzialność posiłkowa (art. 24 i art. 25) znajduje podstawy w art. 42 Konstytucji RP.

Aby udzielić odpowiedzi na tak sformułowane pytanie, należy w pierwszej kolejności wyjaśnić istotę odpowiedzialności posiłkowej. Odpowiedzialność ta regulowana jest art. 24 k.k.s., który stanowi, że: „Za karę grzywny wymierzoną sprawcy przestępstwa skarbowego czyni się w całości albo w części

\footnotetext{
${ }^{2}$ Wyrok Trybunału Konstytucyjnego z 6 listopada 2012 r., K 21/11, OTK-A 2012, nr 10, poz. 119, uzasadnienie, s. 13.

${ }^{3}$ B. Nita, Materialnoprawne $i$ procesowe zatożenia ustawy o odpowiedzialności podmiotów zbiorowych za czyny zabronione pod groźba kary, cz. I, „Radca Prawny” 2003, nr 5, s. 45.
} 
odpowiedzialną posiłkowo osobę fizyczną, osobę prawną albo jednostkę organizacyjną niemająca osobowości prawnej, której odrębne przepisy przyznaja zdolność prawna, jeżeli sprawcą czynu zabronionego jest zastępca tego podmiotu prowadzący jego sprawy jako pełnomocnik, zarządca, pracownik lub działający w jakimkolwiek innym charakterze, a zastępowany podmiot odniósł albo mógł odnieść z popełnionego przestępstwa skarbowego jakąkolwiek korzyść majątkową". Przepis ten stosuje się odpowiednio do ściągnięcia równowartości pieniężnej przepadku przedmiotów. Niezależnie od nałożenia odpowiedzialności posiłkowej sąd zobowiązuje podmiot, który uzyskał korzyść majątkową, do jej zwrotu w całości albo w części na rzecz Skarbu Państwa lub jednostki samorządu terytorialnego; nie dotyczy to korzyści majątkowej podlegającej zwrotowi na rzecz innego uprawnionego podmiotu.

Odpowiedzialność posiłkowa to osobista odpowiedzialność majątkowa za grzywnę wymierzoną sprawcy przestępstwa skarbowego (nie odnosi się do wykroczeń skarbowych), a także ewentualnie za ściagnnięcie równowartości przedmiotów przepadku. Odpowiedzialnym posiłkowo nie może być osoba ponosząca odpowiedzialność karną w związku z tym przestępstwem, za które miałaby ponosić odpowiedzialność posiłkową w zakresie skazania na grzywnę jeszcze innej osoby. Można ją natomiast nałożyć na osobę uniewinnioną od takiego zarzutu, chociaż skazano innego współoskarżonego, albo na współoskarżonego, którego skazano w tym samym procesie, ale za inne przestępstwo skarbowe niż to, którego dotyczy odpowiedzialność posiłkowa ${ }^{4}$.

Odpowiedzialność posiłkowa jest wyrazem troski ustawodawcy o egzekwowanie należności publicznoprawnych i wyrównanie uszczerbku finansowego Skarbu Państwa lub innych budżetów. Wskazuje na to regulacja art. 114 $\S 1$ k.k.s., w której podkreślono, że zadaniem postępowania jest tu także -oprócz ogólnych zasad procesu karnego - takie ukształtowanie postępowania, aby osiaggnięte zostały cele tego postępowania w zakresie wyrównania uszczerbku finansowego Skarbu Państwa i innych uprawnionych podmiotów ${ }^{5}$. Wyłania się $\mathrm{z}$ tego naturalna funkcja instytucji odpowiedzialności posiłkowej, którą jest zabezpieczenie realnego wykonania kar i środków karnych o charakterze majątkowym, czyli szeroko pojętego interesu finansowego państwa. Natomiast jej istota sprowadza się do przerzucenia odpowiedzialności za karę grzywny wymierzoną sprawcy przestępstwa oraz za nałożony nań środek karny ściagnięcia równowartości pieniężnej przepadku, gdy nie można ich wyegzekwować od sprawcy czynu, na inny podmiot, pozostający z tym sprawcą w określonych przez prawo karne skarbowe relacjach.

Swoisty charakter odpowiedzialności posiłkowej przejawia się jednak w tym, że w przeciwieństwie do odpowiedzialności karnej skarbowej, którą w świetle k.k.s. ponosić mogą wyłącznie osoby fizyczne, odpowiedzialność posiłkowa nałożona zostać może zarówno na osoby fizyczne, jak i na osoby prawne oraz jednostki organizacyjne niemające osobowości prawnej, a którym to odrębne przepisy przyznaja zdolność prawną.

${ }^{4}$ T. Grzegorczyk, Kodeks karny skarbowy. Komentarz, Wolters Kluwer Polska 2009, s. 118-119.

${ }^{5}$ L. Wilk, J. Zagrodnik, Prawo karne skarbowe, Warszawa 2009, s. 12. 
Odpowiedzialność posiłkowa może być nałożona na wyżej wskazane podmioty, gdy spełnione są łącznie następujące przesłanki: 1) sprawca przestępstwa skarbowego jest zastępcą tego podmiotu prowadzącym jego sprawy jako pełnomocnik, zarządca, pracownik lub działający w jakimkolwiek innym charakterze, 2) zastępowany podmiot odniósł lub mógł odnieść z popełnionego przestępstwa jakąkolwiek korzyść majątkową ${ }^{6}$.

Biorąc powyższe pod uwagę, należy rozważyć, czy odpowiedzialność posiłkowa mieści się $\mathrm{w}$ odpowiedzialności sprawczej, o której mowa w art. 42 Konstytucji RP. Nie ulega wątpliwości, że odpowiedzialność sprawcy przestępstwa skarbowego mieści się $\mathrm{w}$ pojęciu odpowiedzialności karnej definiowanej w Konstytucji RP. Jaki natomiast charakter ma odpowiedzialność pociagnniętego do odpowiedzialności posiłkowej, skoro nie dopuścił się on przestępstwa skarbowego? Celem ustalenia, czy odpowiedzialność, o której mowa, mieści się $\mathrm{w}$ definicji określonej $\mathrm{w}$ art. 42 Konstytucji RP, należy wyjść od określenia relacji między sprawcą przestępstwa skarbowego a odpowiedzialnym posiłkowo.

Ich wzajemne powiązania prowadzą do przyjęcia założenia, że zachodzi tu możliwość czerpania korzyści przez podmiot pociagnięty do odpowiedzialności posiłkowej, a wynikłej z przestępstwa popełnionego przez sprawcę. Te wzajemne stosunki (oparte na bliższej więzi osobistej lub prawnej) sugerują, że podmiot zastępowany bezpośrednio lub pośrednio partycypować może w zyskach pochodzących z przestępstwa ${ }^{7}$.

W doktrynie pojawiaja się opinie, że odpowiedzialność posiłkowa nie ma konotacji karnej. Opiera się na przyjętej z prawa cywilnego zasadzie winy w nadzorze czy też winy w wyborze swojego zastępcy, ale z art. 24 k.k.s. nie da się wyinterpretować uzależnienia jej od wykazania winy. Gdyby miała ona uzależniać omawianą instytucję, racjonalny ustawodawca wprowadziłby ją do k.k.s. W doktrynie pojawiaja się też poglądy, że odpowiedzialność posiłkowa opiera się za zasadzie ryzyka lub ,elementach zasady ryzyka" ${ }^{8}$, ale i tych zasad ustawodawca nie wprowadził do art. 24 k.k.s.

Wobec powyższego przyjąć należy, że ustawodawca, wprowadzając art. 42 Konstytucji RP odpowiedzialność karną, nie odnosi jej do odpowiedzialności posiłkowej. Ewentualnym przejawem jej dopuszczenia jest to, że jest ona następstwem popełnienia przez podmiot zastępujący przestępstwa skarbowego i wprowadzona została do polskiego prawodawstwa aktem rangi ustawowej. Przy tej odpowiedzialności wystarczy po stronie podmiotu pociagniętego do niej sama świadomość, że jest zastępowany, a ponosi tę odpowiedzialność za to, że osiagnął lub mógł osiągnąć jakąkolwiek korzyść majątkową z przestępstwa popełnionego przez zastępcę.

${ }^{6}$ T. Grzegorczyk, Odpowiedzialność positkowa w obecnym prawie karnym skarbowym $i$ w przysztej u.k.s., „Palestra” 1997, nr 1-2, s. 24; Z. Siwik, Systematyczny komentarz do ustawy karnej skarbowej. Część ogólna, Wrocław 1993, s. 337; F. Prusak, Prawo i postepowanie karne skarbowe, Warszawa 2003, s. 46; G. Bogdan et al., Kodeks karny skarbowy. Komentarz, Gdańsk 2007, s. 130.

${ }^{7}$ A. Kisiel, Odpowiedzialność positkowa na gruncie przepisów kodeksu karnego skarbowego, w: L. Bogunia (red.), Nowa kodyfikacja prawa karnego, t. 14, Wrocław 2003, s. 265-266; G. Skowronek, Szczególne strony postępowania w sprawach karnych skarbowych, „Prokuratura i Prawo” 2005, nr 7-8, s. 168.

${ }^{8}$ L. Wilk, J. Zagrodnik, Kodeks karny skarbowy. Komentarz, Warszawa 2007, s. 118. 
Nie można także zapominać, że odpowiedzialność posiłkowa aktualizuje się dopiero wtedy, gdy sprawca przestępstwa skarbowego nie uiści kary grzywny lub równowartości przepadku i zostanie stwierdzone, że kary tej lub środka karnego nie można ściagnnąć $\mathrm{w}$ drodze egzekucji. I to też odróżnia tę odpowiedzialność od odpowiedzialności karnej, przy której sprawca ponosi odpowiedzialność za własny czyn i za niego ponosi konsekwencje prawnokarne. Natomiast odpowiedzialność posiłkowa ma charakter czysto fiskalny i dlatego jest to szczególny rodzaj odpowiedzialności (określanej w doktrynie mianem niesprawczej), ale nie o znamionach odpowiedzialności karnej skarbowej. Odpowiedzialność posiłkowa ma tylko jedną cechę odpowiedzialności karnej. Jest nią osobisty charakter, jako osobistej odpowiedzialności majątkowej (za cudzy czyn). Jej istota wyraża się w dążeniu do pełnej kompensacji przynależnych Skarbowi Państwa należności publicznoprawnych.

Konkludując, odpowiedzialność posiłkowa nie ma charakteru odpowiedzialności stricte karnej, ale jest odrębną odpowiedzialnością wprowadzoną art. 24 i 25 k.k.s., i jako takiej nie można jej wyprowadzać wprost z art. 42 ust. 1 Konstytucji RP, odnoszącej się do odpowiedzialności karnej.

\section{ZOBOWIAZANIE DO ZWROTU KORZYŚCI MAJĄTKOWEJ PRZEWIDZIANE W KODEKSIE KARNYM I KODEKSIE KARNYM SKARBOWYM}

Niewatpliwie instytucja przewidziana w przepisach art. 52 k.k. i art. 24 $\S 5$ k.k.s. jest swoistą odpowiedzialnością prawna, chociaż ustawodawca nie stanowi wprost o odpowiedzialności. Przez odpowiedzialność prawną rozumie się bowiem ,obowiązek ponoszenia przewidzianych przez normę prawa konsekwencji zachowania się własnego lub innych osób" ". Ma ona miejsce wówczas, gdy dochodzi do naruszenia norm prawnych bądź wynika ze związania adresata normy prawnej określonymi przez prawo skutkami tego zachowania ${ }^{10}$. Normy w powołanych artykułach przenoszą w zakresie zwrotu bezprawnej korzyści majątkowej odpowiedzialność ze sprawcy działania na inną osobę. Jest nią podmiot, który uzyskał korzyść majątkową z przestępstwa popełnionego przez skazanego ${ }^{11}$.

Odpowiedzialność z art. 52 k.k. jest zbliżona do odpowiedzialności posiłkowej poprzez m.in. istnienie powiązania między podmiotem odpowiedzialnym a sprawca. Oba rodzaje odpowiedzialności można określić jako odpowiedzialność zależną, z racji uzależnienia jej od skazania sprawcy. Dotyczy ona układu reprezentant-reprezentowany ${ }^{12}$. Zasadą tej odpowiedzialności jest sam

\footnotetext{
${ }^{9}$ Mata encyklopedia prawa, red. Z. Rybicki, Warszawa 1980, s. 401.

${ }^{10}$ A. Redelbach, Wstęp do prawoznawstwa, Torun 1999, s. 227.

${ }^{11}$ Fragmenty monografii D. Kaczorkiewicz, Pozycja podmiotu zobowiazanego do zwrotu korzyści majatkowej (art. 52 kodeksu karnego) w polskim procesie karnym, Torun 2005.

${ }^{12}$ T. Bojarski, Nowe środki karne $i$ formy załatwienia spraw karnych (Uwagi na tle nowego prawa karnego), w: Nowe prawo karne procesowe. Ksiega ku czci Profesora Wiestawa Daszkiewicza, red. T. Nowak, Poznań 1999, s. 141.
} 
fakt uzyskania korzyści majątkowej. Przy czym sprawca nie musi działać w celu jej przysporzenia innemu podmiotowi ${ }^{13}$.

Odpowiedzialność ta ma charakter majątkowy ${ }^{14}$ ze względu na przewidziany środek reakcji ${ }^{15}$. Posiada ona cechę materialności, gdyż wynika z czynu niedozwolonego, który spowodował szkodę i w konsekwencji tego mieści się w odpowiedzialności cywilnej ${ }^{16}$. Przez co nie jest uznawana za odpowiedzialność karną, co pozwala na pociągnięcie do niej innych podmiotów niż osoby fizyczne $^{17}$. Przyjmuje się bowiem, że podmiot niebędący osobą fizyczną może być pociągnięty jedynie do odpowiedzialności cywilnej z tytułu czynu niedozwolonego popełnionego przez inną osobę ${ }^{18}$.

Jednakże zakładając uniwersalność podziału na odpowiedzialność majątkową i niemajątkową, zakwalifikowanie odpowiedzialności z art. 52 k.k. i art. 24 $\S 5$ k.k.s. do jednej z nich nie przesądza o tym, czy należy ona do odpowiedzialności karnej, czy też cywilnej.

Przy odpowiedzialności podmiotu zobowiązanego do zwrotu korzyści majątkowej, uzyskanej z przestępstwa popełnionego przez skazanego, nie występuje czynnik subiektywny. Nie ma znaczenia nastawienie psychiczne podmiotu odpowiedzialnego. Brak podstaw do postawienia mu zarzutu. Ponadto odpowiada osoba trzecia, to jest taka, która nie jest sprawca. $Z$ powyższego wywieść można wniosek, że odpowiedzialność ta należy do grupy odpowiedzialności przedmiotowej za postępowanie lub jego skutki niezależnie od kwestii oceny strony podmiotowej. Przesłanką pociagnięcia do tej odpowiedzialności przedmiotowej jest wyłącznie ujemna kwalifikacja czynu (jego następstw) czy zdarzeń normatywnie przypisywalnych sprawcy, jako rezultat jego postępowania. Odpowiada podmiot, który zachował się w taki sposób, że zaistniały negatywne skutki. Skutki te moga być czynami innych osób, za które ponosi odpowiedzialność sprawca pierwotnego zachowania. Bez znaczenia jest przy tym to, czy można mu postawić zarzut $\mathrm{np}$. $\mathrm{z}$ tytułu nienależytego nadzoru ${ }^{19}$.

Odpowiedzialność przewidziana w omawianych normach nie opiera się na żadnej z występujących dotychczas zasad odpowiedzialności stanowiących łącznik pomiędzy czynem a osobą odpowiedzialnością. Zasada taką będzie w tym wypadku wyłącznie uzyskanie korzyści majątkowej, która jest bezprawna przez to, że wywodzi się z przestępstwa popełnionego przez inną osobę. Samo jej osiagnnięcie przez osobę trzecią daje podstawę do pociąnnięcia do

${ }^{13}$ W. Daszkiewicz, Zobowiazanie do zwrotu korzyści majatkowej uzyskanej wskutek przestępstwa popetnionego przez inna osobę, w: Nowa kodyfikacja karna K.p.k. Krótkie komentarze, z. 16, Warszawa 1998, s. 119-121 i 128-129.

${ }_{14}$ Z. Gostyński, Nowe instytucje prawa karnego nawiazujace do prawa karnego skarbowego, „Prokuratura i Prawo” 1998, nr 10, s. 18-22.

${ }^{15}$ W. Lang, Spór o pojęcie odpowiedzialności prawnej, „Zeszyty Naukowe Uniwersytetu Mikołaja Kopernika", z. 37, 1968, s. 57-58.

${ }^{16}$ M. Grudziński (red.), Prawo na co dzień, Warszawa 1961, s. 140.

${ }^{17}$ T. Grzegorczyk, Sytuacja prawna podmiotu odpowiedzialnego za zwrot korzyści uzyskanej z przestepstwa innej osoby w procesie karnym, w: Nowa kodyfikacja karna K.p.k. Krótkie komentarze, z. 1, Warszawa 1997, s. 55-56.

18 J. Bratoszewski et al., Kodeks postepowania karnego Komentarz, t. 2, Warszawa 1998, s. 373.

${ }^{19}$ W. Lang, op. cit., s. 53-59. 
odpowiedzialności prawnej. Związek pomiędzy podmiotem odpowiedzialnym a czynem przestępnym, który tę odpowiedzialność powoduje, wynika także $\mathrm{z}$ działania przez odpowiedzialnego $\mathrm{w}$ imieniu lub interesie sprawcy przestępstwa. Wprawdzie wydawać by się mogło, że odpowiedzialność ta jest oparta na zasadzie winy w wyborze bądź nienależytym dozorze, to jednak pociągnięcie do niej nie wymaga wykazania tych okoliczności ${ }^{20}$.

Analiza głównych cech odpowiedzialności karnej prowadzić może do wniosku, że zobowiązanie do zwrotu korzyści na rzecz Skarbu Państwa nie jest odpowiedzialnością karną, w szczególności ze względu na jej przedmiotowy charakter oparty nie na zasadzie winy, lecz na zasadzie zbliżonej do słuszności, ryzyka czy bezpodstawnego wzbogacenia ${ }^{21}$. Wydaje się, że wątpliwości co do charakteru omawianej odpowiedzialności wywodzą się z tego, że prawo karne przewiduje możliwość pociagnięcia oskarżonego w procesie karnym do odpowiedzialności cywilnej i tzw. akcję cywilną w postępowaniu karnym. Do rozpoznanych w efekcie tego roszczeń cywilnych maja zastosowanie przepisy prawa cywilnego materialnego, a postępowanie w ich przedmiocie prowadzone jest na podstawie Kodeksu postępowania karnego i odpowiednio stosowanych przepisów prawa cywilnego procesowego ${ }^{22}$.

Jednakże odpowiedzialność cywilna cechuje się tym, że wynika z przepisów prawa cywilnego, które przewidują odpowiedzialność z ustawy bądź umowy. Stanowi obowiązek ponoszenia materialnych konsekwencji zachowania się własnego lub innej osoby, przez co ma charakter majątkowy. Wyróżnia się odpowiedzialność deliktową i kontraktową za czyny własne i cudze, a także za zwierzęta i rzeczy. Oparta jest głównie na zasadzie winy oraz na zasadzie słuszności i ryzyka. W każdym wypadku wymagane jest istnienie szkody oraz związku przyczynowego pomiędzy szkodą a zdarzeniem, z którym norma prawna wiąże odpowiedzialność ${ }^{23}$.

Rozstrzygnięcie sądu karnego w zakresie zasądzenia odszkodowania w wyniku uwzględnienia powództwa cywilnego, bądź z urzędu, należy do odpowiedzialności cywilnej. Kontrowersyjny jest już jednak charakter orzeczenia o obowiązku naprawienia szkody, jako środek karny powoduje bowiem pociagnnięcie do odpowiedzialności karnej ${ }^{24} \mathrm{Z}$ drugiej jednak strony wykazuje on cechy właściwe konstrukcjom prawnym z zakresu prawa cywilnego ${ }^{25}$.

${ }^{20}$ R. A. Stefański, Obowiazek zwrotu korzyści majątkowej uzyskanej z przestępstwa przez inna osobę, „Prokuratura i Prawo” 2000, z. 3, s. 124.

${ }^{21}$ M. Miąsik, Instytucja zobowiazania do zwrotu bezprawnie uzyskanej korzyści majatkowej (art. 52 k.k.) w świetle badań ankietowych, „Czasopismo Prawa Karnego i Nauk Penalnych” 2007, nr 2, s. 153.

${ }^{22}$ A. Cader et al., Prawnomaterialne i procesowe problemy odpowiedzialności podmiotu zobowiazanego do zwrotu korzyści majatkowej na podstawie art. 52 k.k., „Nowa Kodyfikacja Prawa Karnego” 2003, nr 13 , s. 11.

${ }^{23}$ Mata encyklopedia..., s. 393-394.

${ }^{24}$ Zob. np.: Z. Gostyński, Obowiazek naprawienia szkody w prawie karnym, Warszawa 1999, s. 25-28; Z. Sienkiewicz, Kilka uwag o funkcjach obowiazku naprawienia szkody w projekcie k.k., „Przegląd Sądowy” 1994, nr 1, s. 80; J. Kowalska, D. Skrzyńska, Obowiazek naprawienia szkody jako środek karny, ,Wojskowy Przegląd Prawniczy” 2001, nr 1, s. 40-47.

${ }^{25}$ Tak np. M. Szewczyk, Kilka uwag dotyczacych odszkodowania jako środka karnego w projekcie kodeksu karnego, „Palestra” 1995, nr 1-2, s. 70. 
Należy także zauważyć, że w efekcie preferowania instytucji, które doprowadzić moga do nieopłacalności przestępstwa, a tym samym będą miały oddziaływanie prewencyjne, wprowadzono szereg instytucji, których celem nadrzędnym jest wyeliminowanie negatywnych materialnie skutków czynu przestępnego ${ }^{26}$. Zjawisko to uwidacznia się przede wszystkim w rozszerzeniu katalogu środków karnych o takim celu. Instytucje prawa karnego zaczynaja pokrywać się z instytucjami prawa cywilnego. Widoczny jest trend kumulowania realizacji celów karnych i odszkodowawczych w jednym postępowaniu przy okazji pociaggania do odpowiedzialności karnej. Ma to swoje uzasadnienie w ekonomice postępowania. Jest też przejawem zmierzania do wprowadzenia takich środków reakcji karnej, które doprowadzą do nieopłacalności przestępstwa. W takiej sytuacji wprowadzenie wymienionych rozwiązań w prawie karnym powoduje, że różnymi drogami dojdzie do naprawienia szkody. Przestępstwo staje się nieopłacalne zarówno dla sprawcy, jak i osób, które wprawdzie nie są sprawcami, lecz osiągnęły z przestępstwa korzyść. Wzmocnienie funkcji kompensacyjnej środków karnych nie jest jednak równoznaczne z przekształceniem ich $\mathrm{w}$ odpowiedzialność cywilną. Za środek karny, choć o szczególnym charakterze, należy także uznać zobowiązanie do zwrotu korzyści majątkowej ${ }^{27}$.

Przy instytucji z art. 52 k.k. i art. $24 \S 5$ k.k.s. pojawia się, poza zagadnieniem styku prawa karnego $\mathrm{z}$ cywilnym, problem pociagnięcia do odpowiedzialności innej osoby niż sprawca przestępstwa. Zgodnie bowiem z art. 42 ust. 1 Konstytucji RP odpowiedzialności karnej podlega ten tylko, kto dopuścił się czynu zabronionego pod groźbą kary przez ustawę obowiązująca w czasie jego popełnienia. Do odpowiedzialności karnej może być bowiem pociągnięta wyłącznie osoba fizyczna. Tymczasem odpowiedzialnym na mocy art. 52 k.k. i art. $24 \S 5$ k.k.s. może być, poza osobą fizyczną, także osoba prawna i jednostka organizacyjna nieposiadająca osobowości prawnej. Należy jednak zauważyć, że w ustawodawstwie polskim coraz szersze zastosowanie ma odpowiedzialności osób prawnych ${ }^{28}$.

Omawiane konstrukcje wskazują na to, że sprawca ponosi odpowiedzialność za swój czyn, a podmiot z art. 52 k.k. i art. $24 \S 5$ k.k.s. za skutki tego czynu będącego przestępstwem czy przestępstwem skarbowym. Jest to więc odpowiedzialność niesprawcza osoby o różnej podmiotowości prawnej przewidziana obok odpowiedzialności sprawcy ${ }^{29}$.

${ }^{26}$ W. Chlebus, Srodki karne jako nowy system sankcji w prawie karnym, Nowa kodyfikacja prawa karnego, t. 4, red. L. Bogunia, Wrocław 1999, s. 37-39.

${ }^{27}$ M. Miąsik, op. cit., s. 153.

${ }^{28}$ O czym świadczy chociażby ustawa z 16 kwietnia 1993 r. o zwalczaniu nieuczciwej konkurencji, Dz. U. 1996, Nr 106, poz. 496 ze zm., w tym zmianą wynikającą z ustawy z 9 września 2000 r. o zmianie ustawy - Kodeks karny, ustawy - Kodeks postępowania karnego, ustawy o zwalczaniu nieuczciwej konkurencji, ustawy o zamówieniach publicznych oraz ustawy - Prawo bankowe, Dz. U. 2000, Nr 93, poz. 1027.

${ }^{29}$ M. Miąsik, op. cit., s. 153. 


\section{ODPOWIEDZIALNOŚĆ PODMIOTÓW ZBIOROWYCH ZA CZYNY ZABRONIONE POD GROŹBĄ KARY}

Problematyka, która związana jest z niniejszą częścią opracowania, opiera się na ustawie z 28 października $2000 \mathrm{r}$. o odpowiedzialności podmiotów zbiorowych za czyny zabronione pod groźbą kary ${ }^{30}$. W ustawie tej znalazła się definicja podmiotu zbiorowego, którym w rozumieniu tej ustawy jest osoba prawna oraz jednostka organizacyjna niemająca osobowości prawnej, której odrębne przepisy przyznają zdolność prawną, z wyłączeniem Skarbu Państwa, jednostek samorządu terytorialnego i ich związków. Ponadto podmiotami zbiorowymi są też spółki handlowe z udziałem Skarbu Państwa, jednostki samorządu terytorialnego lub związki tych jednostek, spółka kapitałowa $\mathrm{w}$ organizacji, podmiot $\mathrm{w}$ stanie likwidacji oraz przedsiębiorcy niebędący osobami fizycznymi, a także zagraniczne jednostki organizacyjne. Podmioty, które zostały wymienione przez ustawodawcę, podlegają odpowiedzialności za przestępstwa, które zostały wymienione w tym akcie prawnym, a zostały popełnione przez osobę fizyczną związaną z danym podmiotem zbiorowym. Osoba fizyczna jednak, popełniając dany czyn zabroniony, musi:

- działać w imieniu lub w interesie podmiotu zbiorowego w ramach uprawnienia lub obowiązku do jego reprezentowania, podejmowania $\mathrm{w}$ jego imieniu decyzji lub wykonywania kontroli wewnętrznej albo przy przekroczeniu tego uprawnienia lub niedopełnieniu tego obowiązk;

- zostać dopuszczona do działania w wyniku przekroczenia uprawnień lub niedopełnienia obowiązków przez osobę, o której mowa w punkcie 1;

- działać w imieniu lub w interesie podmiotu zbiorowego, za zgodą lub wiedzą osoby, o której mowa w punkcie 1 .

Ponadto czynu zabronionego mogła się też dopuścić osoba fizyczna, która jest przedsiębiorcą bezpośrednio współdziałającym z podmiotem zbiorowym w realizacji celu prawnie dopuszczalnego. W wyniku działań podjętych przez wyżej określone osoby fizyczne, by można było mówić o odpowiedzialności tegoż podmiotu zbiorowego za czyn zabroniony pod groźba kary, podmiot ten, w wyniku działania osoby fizycznej osiągnął jakąkolwiek korzyść, chociażby byłaby to korzyść niemajątkowa. Dalsza analiza przepisów ustawy prowadzi jednak do wniosku, że aby podmiot zbiorowy mógł odpowiadać za działania wymienionych osób fizycznych, to musiałoby z jego strony dojść do co najmniej braku należytej staranności w wyborze osoby fizycznej, wymienionej w tirecie 2 i 3 , lub co najmniej braku należytego nadzoru nad ta osoba - ze strony organu lub przedstawiciela podmiotu zbiorowego.

Kolejnym warunkiem odpowiedzialności podmiotu zborowego jest to, by czyn, który został popełniony przez osobę fizyczna, został uprzednio stwierdzony prawomocnym wyrokiem skazującym tę osobę, wyrokiem warunkowo umarzającym wobec niej postępowanie karne albo postępowanie o przestępstwo skarbowe, orzeczeniem o udzielenie tej osobie zezwolenia na dobrowolne

${ }^{30}$ Dz. U. 2002, Nr 197, poz. 1661. 
poddanie się odpowiedzialności albo orzeczeniem sądu o umorzeniu przeciwko niej postępowania z powodu okoliczności wyłączających ukaranie sprawcy.

Poważny problem pojawił się w momencie próby określenia zakresu charakteru prawnego odpowiedzialności, która została uregulowana w przedmiotowej ustawie. Rozbieżności w próbie określenia tej odpowiedzialności pojawiły się już na gruncie uchwalenia ustawy w 2002 r., co dało asumpt do podania w wątpliwość zgodności z Konstytucją RP wielu sformułowanych w niej przepisów. Na gruncie powyższego wypowiedział się Trybunał Konstytucyjny w wyroku z 3 listopada 2004 r. ${ }^{31}$, który to nie rozstrzygnął wszystkich problemów, o czym będzie mowa dalej. Podobnie rzecz się przedstawia po dokonaniu zmian w powyższej ustawie ustawą z 28 lipca 2005 r. o zmianie ustawy o odpowiedzialności podmiotów zbiorowych za czyny zabronione pod groźba kary. Pierwotnie w uzasadnieniu projektu ustawy wskazano, że odpowiedzialność podmiotów zbiorowych ma być odpowiedzialnością karną. Jednak twórcy projektu nie rozwodzili się szerzej nad tą problematyka, stwierdzono jedynie lakonicznie, że: „Projekt ustawy określa zasady odpowiedzialności podmiotów zbiorowych za przestępstwa lub przestępstwa skarbowe, oraz zasady postępowania w przedmiocie takiej odpowiedzialności" ${ }^{32}$. Jednakże w toku prac nad projektem dokonano zmiany: usunięto z nazwy ustawy przymiotnik ,karna” i zastąpiono go określeniem ,odpowiedzialność za czyny zabronione pod groźba kary". Zmiana ta jednak nie może sama w sobie przesądzać o tym, z jakiego rodzaju odpowiedzialnością mamy do czynienia ${ }^{33}$.

Wskazać należy, że w doktrynie można spotkać dwa ujęcia odpowiedzialności zakreślonej w tej ustawie. Jedno ze stanowisk opowiada się za stwierdzeniem, że mowa jest tam o odpowiedzialności karnej, natomiast inna grupa opowiada się, że w ustawie można mówić o nowym rodzaju odpowiedzialności, która ma charakter represyjny, jednak nie jest to odpowiedzialność stricte karna ${ }^{34}$. Uznanie, że omawiana koncepcja odpowiedzialności to odpowiedzialność karna, dlatego byłoby istotne, że przesądzałoby o tym, jakiej dyscypliny ,instrumentarium” znajdzie do niej zastosowanie oraz jaki będzie zakres gwarancji w postępowaniu prowadzonym na podstawie przedmiotowej ustawy ${ }^{35}$.

W kwestii modeli odpowiedzialności podmiotów zbiorowych można wskazać trzy takie koncepcje. Pierwsza z nich jest odpowiedzialność zastępcza, która polega na tym, że podmiot zbiorowy ponosi odpowiedzialność za czyny wszystkich osób, które działają na jego rzecz w ramach powierzonych im zadań, a także za czyny tych osób podjęte bezprawnie wbrew woli osoby powierzającej ich wykonanie, a nawet wyraźnie przez tę osobę zakazane. Jest to jeden z rodzajów odpowiedzialności obiektywnej. Możliwość przypisania przestępstwa

${ }^{31}$ Wyrok TK z 3 listopada 2004 r., K 18/03, OTK-A 2004, nr 10, poz. 103.

${ }^{32}$ Uzasadnienie rządowego projektu ustawy o odpowiedzialności karnej podmiotów zbiorowych (druk sejmowy nr 706). Historia prac nad projektem ustawy http://ks.sejm.gov.pl/proc4/opisy/706.htm.

${ }^{33}$ M. Pniewska, Problematyka charakteru prawnego odpowiedzialności podmiotów zbiorowych za czyny zabronione pod groźba kary w prawie polskim, ,Studia Iuridica Toruniensia” 6, 2010, s. 187.

${ }^{34}$ M. Pniewska, op. cit., s. 188.

${ }^{35}$ D. Habrat, Materialnoprawne aspekty odpowiedzialności podmiotów zbiorowych w polskim prawie karnym, Toruń 2008, s. 102-103. 
temu ostatniemu warunkuje bowiem pociagnnięcie do odpowiedzialności podmiotu zbiorowego ${ }^{36}$.

Kolejnym modelem odpowiedzialności jest odpowiedzialność identyfikacyjna, która sprowadza się do założenia, że czyny osób będących w strukturze danej korporacji są czynami samej korporacji ${ }^{37}$.

Trzecim z kolei ujęciem odpowiedzialności podmiotów zbiorowych jest model bezpośredniej odpowiedzialności karnej podmiotów zbiorowych. Przyjmuje się tutaj fikcję prawną, że zachowania poszczególnych osób wchodzących w skład podmiotu zbiorowego łączy się w jedną całość - zachowanie stanowiące podstawę odpowiedzialności osoby prawnej. Koncepcja ta umożliwia pociągnięcie do odpowiedzialności podmiotu zbiorowego nie tylko wtedy, gdy zachowania pojedynczych osób wchodzących w jego skład stanowią osobne przestępstwa, lecz także wtedy, gdy każde z osobna nie stanowi przestępstwa, jednakże ich suma ma już taki charakter ${ }^{38}$.

Analizy literatury pozwala wskazać, że za odpowiedzialnością karna podmiotów zbiorowych opowiadają się m.in. S. Waltoś ${ }^{39}$, B. Nita ${ }^{40}$, B. Namysłowska-Gabrysiak ${ }^{41}$. Natomiast przeciwnikami tej koncepcji są m.in. M. Filar ${ }^{42}$, K. Wicher ${ }^{43}$, B. Mik ${ }^{44}$, A. Zachuta ${ }^{45}$, R. Zawłocki ${ }^{46}$. Wątpliwości przedstawicieli doktryny nie budzi jednak fakt, że przewidziana w ustawie odpowiedzialność jest na pewno odpowiedzialnością represyjną. Podkreślić jednak należy - jak czyni to B. Nita - że pojęcie odpowiedzialności karnej nie tylko występuje na gruncie ustaw karnych, ale również jest ono obecne w akcie o charakterze generalnym, którym jest Konstytucja $\mathrm{RP}^{47}$.

Przedmiotowym zagadnieniem zajmował się Trybunał Konstytucyjny, który w uzasadnieniu wyroku z 3 listopada 2004 r. stwierdził, że nie ma wątpliwości, iż ustawodawca uchwalając ustawę o odpowiedzialności podmiotów zbiorowych za czyny zabronione pod groźba kary, dążył do stworzenia odrębnej odpowiedzialności. Pomimo jednak występowania pewnych rozbieżności, jakie pojawiły

${ }^{36}$ B. Nita, Model odpowiedzialności podmiotów zbiorowych za czyny pod groźba kary, „Państwo i Prawo" 2003, z. 6, s. 18.

37 M. Pniewska, op. cit., s. 190.

${ }^{38}$ B. Namysłowska-Gabrysiak, Ustawa o odpowiedzialności podmiotów zbiorowych za czyny zabronione pod groźba kary. Komentarz, Kraków 2004, s. 32.

${ }^{39} \mathrm{~S}$. Waltoś, Odpowiedzialność karna podmiotów zbiorowych - stary problem legislacyjny na nowo, w: A. Łopatka, B. Kunicka-Michalska, S. Kielewicz (red.), Prawo. Społeczeństwo. Jednostka. Ksiega jubileuszowa dedykowana Profesorowi Leszkowi Kubickiemu, Warszawa 2003, s. 396-406.

${ }^{40}$ B. Nita, op. cit., s. 17.

${ }^{41}$ B. Namysłowska-Gabrysiak, op. cit., s. 62 i n.

${ }^{42}$ M. Filar, Z. Kwaśniewski, D. Kala, Komentarz do ustawy o odpowiedzialności podmiotów zbiorowych za czyny zabronione pod groźba kary, Toruń 2006, s. 26.

${ }^{43} \mathrm{~K}$. Wicher, Zakres podmiotowy ustawy z dnia 28 października $2002 \mathrm{r}$. o odpowiedzialności podmiotów zbiorowych za czyny zabronione pod groźba kary - pojęcie podmiotu zbiorowego w świetle wyroku Trybunatu Konstytucyjnego z dnia 3 listopada 2004 r., „Radca Prawny” 2005, nr 4, s. 73.

${ }_{4}$ B. Mik, Charakter prawny odpowiedzialności podmiotów zbiorowych w świetle ustawy $z$ dnia 28 października 2002 r., „Przegląd Sądowy” 2003, nr 7-8, s. 67.

${ }^{45}$ A. Zachuta, Specyfika odpowiedzialności podmiotów zbiorowych za czyny zabronione pod groźba kary, „Prokuratura i Prawo” 2003, nr 11, s. 147 i n.

${ }^{46}$ R. Zawłocki, Prawo karne gospodarcze. Zarys prawa, Warszawa 2007, s. 137-138.

${ }^{47}$ B. Nita, op. cit., s. 17-18. 
się wśród interpretatorów wspomnianej ustawy, należy uznać, że jej regulacje określają odpowiedzialność o charakterze represyjnym. Świadczą o tym przesłanki tej odpowiedzialności, a przede wszystkim represyjny cel i funkcja orzekanych wobec podmiotów zbiorowych kar. Pominięcie przez ustawodawcę w tytule ustawy jej treści bezpośredniego wskazania na ,odpowiedzialność karną" podmiotów zbiorowych można tłumaczyć względami legislacyjnymi użycie tego zwrotu obligowałoby bowiem do stosowania wprost części ogólnej Kodeksu karnego ze względu na art. 116 k.k. Odpowiedzialność karna jest tylko jedną $\mathrm{z}$ form odpowiedzialności, w związku $\mathrm{z}$ którą stosowane sa środki o charakterze represyjnym. Ustawodawcy polskiemu znane sa inne formy postępowań o charakterze represyjnym, które nie są postępowaniami karnymi i - co istotne - prowadzić je mogą (w początkowej fazie) organy niebędące sądami $^{48}$. W uzasadnieniu wyroku Trybunał Konstytucyjny stwierdza, że podobnie jak w wypadku odpowiedzialności dyscyplinarnej czy odpowiedzialności za wykroczenia, konstytucyjne standardy odnoszone do prawa karnego (represyjnego) mają zastosowanie także do odpowiedzialności podmiotów zbiorowych. W szczególności przepisy ustawy podlegają ocenie z punktu widzenia zasady dostatecznej określoności prawa represyjnego, która poza art. 42 Konstytucji RP można wywodzić z zasady ochrony zaufania do państwa i stanowionego w tym państwie prawa (art. 2 Konstytucji RP), a także z punktu widzenia pozostałych gwarancji konstytucyjnych ustanowionych $\mathrm{w}$ art. 42 Konstytucji RP ${ }^{49}$.

Podsumowując, należy stwierdzić, że wprowadzenie przez ustawodawcę do systemu prawnego ustawy o odpowiedzialności podmiotów pod groźbą kary oznaczało wprowadzenie też nowej kategorii odpowiedzialności. Co prawda kategoria ta nie została ściśle zdefiniowania i są rozbieżności w doktrynie w stosunku do jej funkcjonowania, jednakże jednoznacznie należy stwierdzić, że jest to odpowiedzialność o charakterze represyjnym, co zostało też podkreślone przez Trybunał Konstytucyjny. Do odpowiedzialności tej znajdują zastosowanie gwarancje określone w art. 42 Konstytucji RP. Ustawodawca, gdy tworzył podstawy odpowiedzialności podmiotów zbiorowych, nie oparł się na funkcjonujących w świecie modelach, które pozwoliłyby na jej jednoznaczne sklasyfikowanie, co tym samym rodzi wątpliwości. Jednak nie bez znaczenia jest, że problem odpowiedzialności podmiotów zbiorowych pod groźbą kary został dostrzeżony przez ustawodawcę, i niewątpliwe jest to, że wraz z rozwojem gospodarki i konkurencyjności na rynku prowadzi taki stan rzeczy do powstania większych pokus po stronie zarówno osób fizycznych, jak i podmiotów zbiorowych w rozumieniu tej ustawy, nakierowanych na chęć osiągania większych zysków. Może to rodzić niebezpieczeństwo popełniania przy tym przestępstw, które niewątpliwie powinny skutkować odpowiedzialnością podmiotów odpowiedzialnych za to działanie bądź zaniechanie, i to nie tylko tych, które w sposób bezpośredni doprowadziły do powstania stanu niezgodnego z prawem, lecz także tych, które w wyniku tych działań odniosły korzyść, gdyż samo

${ }^{48}$ Wyrok TK z 4 lipca 2002 r., P 12/01, OTK ZU 2003, nr 4/A, poz. 50, s. 731.

${ }^{49}$ Wyrok TK z 3 listopada 2004 r., K 18/03, OTK-A 2004, nr 10, poz. 103. 
pociagnięcie osoby fizycznej do odpowiedzialności jest niewystarczające i często to nie ta osoba odniosła korzyść w ramach swego działania. Celowym jest wymierzenie odpowiedniej sankcji podmiotowi zbiorowemu i tu ustawa pozwala na to. Tym samym ważne jest również wskazanie, że odpowiedzialność, która zostaje przypisana podmiotom zbiorowym, jest zgodna z przepisami Konstytucji. Co prawda w art. 42 Konstytucji RP mówi się o odpowiedzialności sprawczej osób fizycznych, o czym może świadczyć użycie zaimka „kto” - może on świadczyć o tym, że ta odpowiedzialność odnosi się jedynie do osób fizycznych, jednak byłoby to błędne podejście, którego nie należy popierać. Tym samym przepis ten również znajduje zastosowanie do odpowiedzialności odnoszonej do podmiotów zbiorowych, co zostało potwierdzone przez Trybunał Konstytucyjny.

\section{PODSUMOWANIE}

Na zakończenie powyższych rozważań nasuwa się wniosek, że odpowiedzialność posiłkowa nie ma charakteru odpowiedzialności stricte karnej i jest odrębnym rodzajem odpowiedzialności, która nie ma bezpośredniej podstawy normowanej w art. 42 ust. 1 Konstytucji RP. Przepis ten nie odnosi się wprost do odpowiedzialności posiłkowej. Przejawów jej dopuszczenia szukać należy w tym, że aktualizuje się dopiero po popełnieniu przez podmiot zastępujący przestępstwa skarbowego i dopiero wtedy, gdy skazany nie uiści dobrowolnie czy też w drodze egzekucji orzeczonej kary grzywny.

Przy zobowiązaniu do zwrotu korzyści majątkowej podmiot określony w art. 52 k.k. i art. $24 \S 5$ k.k.s. ponosi odpowiedzialność za skutki czynu popełnionego przez sprawcę przestępstwa. Jest to więc także odrębny rodzaj odpowiedzialności, której również nie można wyprowadzić wprost z art. 42 ust. 1 Konstytucji RP, gdyż jest to odpowiedzialność niesprawcza osoby o różnej podmiotowości prawnej obok odpowiedzialności sprawcy, stojąca na styku prawa karnego i prawa cywilnego. Zobowiązanie do zwrotu korzyści majątkowej ma charakter wyjątkowy. Jego kompensacyjny charakter nie wyklucza zaliczenia do odpowiedzialności karnej, ale o odrębnym charakterze niż stricte sprawcza.

Również w zakresie odpowiedzialności podmiotów zbiorowych wprowadzono do ustawodawstwa nową kategorię odpowiedzialności, która też nie ma charakteru odpowiedzialności sprawczej za własny czyn, ale co do której Trybunał Konstytucyjny uznał, że przepis art. 42 ust. 1 Konstytucji RP znajduje do niej zastosowanie.

Wszystkie omówione rodzaje odpowiedzialności niesprawczej powiązane sa z pociągnięciem do odpowiedzialności karnej sprawcy przestępstwa. Skazanie sprawcy przestępstwa daje podstawę do pociągnięcia do odpowiedzialności posiłkowej, do zobowiązania do zwrotu korzyści majątkowej, czy też do pociagnięcia do odpowiedzialności podmiotów zbiorowych. Warunkiem koniecznym stosowania instytucji nałożenia odpowiedzialności posiłkowej, zobowiązania do 
zwrotu korzyści majątkowej czy nałożenia sankcji karnych na podmiot zbiorowy jest więc uznanie osoby fizycznej powiązanej $\mathrm{z}$ określonym podmiotem wymienionych przejawów odpowiedzialności za winną popełnienia przestępstwa, którego skutki dotyczą tego podmiotu. Bez tego nie mogłoby dojść do zastosowania wymienionych instytucji.

Pociagnnięcie do odpowiedzialności niesprawczej pozostaje zatem w ścisłym związku z odpowiedzialnością sprawczą, o której stanowi art. 42 ust. 1 Konstytucji RP. Odpowiedzialność sprawcza jest bowiem podstawowym warunkiem pociągnięcia do odpowiedzialności niesprawczej. Ta ostatnia stanowi niejako reperkusję pociagnnięcia do sprawczej odpowiedzialności karnej. W tym kontekście wymienione rodzaje odpowiedzialności niesprawczej maja swoje umocowanie w cytowanym przepisie Konstytucji.

Zastosowanie instytucji zobowiązania do zwrotu korzyści majątkowej prowadzi do uczynienia nieopłacalnym popełniania przestępstwa we wszystkich jego aspektach i niweluje jego wszystkie skutki. W wypadku zaś odpowiedzialności podmiotów zbiorowych powoduje, że także one ponoszą konsekwencje przestępnych działań, które przyniosły im korzyść. Odpowiedzialność ta stanowi przez to swoista prewencję, gdyż aktywuje te podmioty do przeciwstawiania się popełnianiu przestępstw. Ponadto odbierane są im przedmioty związane $\mathrm{z}$ przestępstwem $\mathrm{w}$ ramach instytucji przepadku.

Jedynie odpowiedzialność posiłkowa, notabene najdłużej funkcjonująca w polskim prawie, nie do końca mieści się w powyżej przedstawionym sposobie rozumowania, które prowadzi do wniosku, że odpowiedzialność niesprawcza dotyczy niwelowania wszelkich konsekwencji przestępstw. Jest ona bowiem przejawem fiskalizmu państwa, które w obawie przed niezapłaceniem grzywny przez sprawcę przestępstwa skarbowego (jej niewyegzekwowaniem) pozwala na przeniesieniem takiego obowiązku na inny podmiot. Przy instytucji odpowiedzialności posiłkowej jakikolwiek jej związek z art. 42 ust. 1 Konstytucji wydaje się wątpliwy.

dr hab. Danuta Tarnowska

Profesor Uniwersytetu Szczecińskiego

dtarnowska@mec.univ.szczecin.pl

dr Dorota Kaczorkiewicz

Uniwersytet Szczecinski

d.kaczorkiewicz@mec.univ.szczecin.pl

mgr Marta Brzezińska

Uniwersytet Szczecinski

mbrzezinska@wpiaus.pl 


\section{NONCAUSATIVE CRIMINAL LIABILITY AS SUBJECT TO PENALTY IN LIGHT OF THE CONSTITUTION OF THE REPUBLIC OF POLAND (ARTICLE 42, ITEM 1)}

\section{Summary}

The analysis focuses on three types of liability, that is ancillary liability (Article 24 and 25 of the Penal and Fiscal Code), pledge to return a financial gain (Article 53 of the Criminal Code and Article $24 \S 5$ of the Penal and Fiscal Code) and criminal liability of collective entities provided in Article 42 item 1 of the Constitution of the Republic of Poland, which refers to direct criminal liability of a perpetrator.

The approach to liability reflected in the Constitution has prompted to seek to determine whether or not Article 42, item 1 refers also to indirect criminal liability, provided for in the abovementioned legal provisions.

The regulations incorporated in the analysed articles lead to a conclusion that convicting the perpetrator of a crime sets the grounds for prosecution under ancillary liability, for obligation to return a financial gain, or for prosecution of collective entities. Therefore, the imperative condition for the application of such measures, subject to the abovementioned types of liability, is to find a natural person associated with the entity guilty of a crime whose consequences affect this entity.

In view of the above, prosecution under noncausative criminal liability remains closely related to causative liability, as provided for in Article 42, item 1 of Poland's Constitution. Causative liability constitutes, as a matter of fact, the fundamental condition for prosecuting under noncausative liability, while noncausative liability constitutes, in a way, a consequence of prosecuting under causative criminal liability. 
Copyright of Journal of Law, Economics and Sociology is the property of Faculty of Law and Administration of Adam Mickiewicz University in Poznan and its content may not be copied or emailed to multiple sites or posted to a listserv without the copyright holder's express written permission. However, users may print, download, or email articles for individual use.

Właścicielem praw autorskich do „Ruchu Prawniczego, Ekonomicznego i Socjologicznego” jest Wydział Prawa i Administracji Uniwersytetu im. Adama Mickiewicza w Poznaniu. Zawartość czasopisma nie może być kopiowana, przesyłana do innych stron internetowych bądź zamieszczana na blogach bez pisemnej zgody wydawcy. Niemniej artykuły można drukować, kopiować lub przesyłać w formie elektronicznej na własny użytek. 